\title{
Appearance and Digestive System Comparison of Lonchura Striata and Copsychus Saularis: Searching for the Effect of Staple Feeding Ingredients on Avian Morphology
}

\section{-Author(s)}

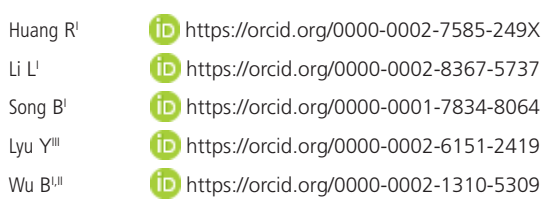

Key Laboratory of Southwest China Wildlife Resources Conservation, Ministry of Education, Shida road 1\#, Nanchong, Sichuan, PR China.

College of Life Science, China West Normal University, Shida road 1\#, Nanchong, Sichuan, PR China.

III Department of Microbiology and Immunology, National University of Singapore, 117597, Singapore.

\section{-Mail Address}

Corresponding author e-mail address Bangyuan Wu, PhD

College of Life Science, China West Normal University, Shida road 1\#, Nanchong, Sichuan, Zip code: 637009, PR China. Phone: +86 13882441768

Email: wubangyuan2008@163.com

\section{- Keywords}

Lonchura striata, Copsychus saularis, Feature parameters, Digestive system, Feeding habits

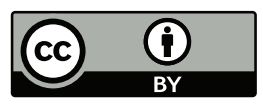

Submitted: 29/April/2020

Approved: 29/July/2020

\section{ABSTRACT}

This study explores the differences of appearance and the digestive systems of two birds (Lonchura striata and Copsychus saularis), which have the same eating pattern in staple ingredients. Each bird was caught naturally and euthanized in appropriate manner, followed by morphology survey on bill, duodenum, jejunum, ileum and appearance of the body parts such as Culmen, Claw, Wing, Tarsus, Toe and Tail. The results showed that the appearance feature between them presented significant differences in the beak length, wing length and tail length, which were correlated to their staple feeding habits. In addition, in the digestive system, the length of duodenum and duodenal indexes showed significant differences $(p<0.05$ or $p<0.01)$, which was considered to be correlated to their predation rate. However, there were no significant differences in jejunum length, ileum length, and the whole digestive tract length and weight, the evidence showed that feeding habits still play a great role in the whole intestine. It is concluded that different staple feeding habits allow the birds to evolve different traits both in appearance and intestine, which aim to improve their predation rate and adapt to different environments. Among all features, duodenum and duodenal were the major objects to get stressed in digestive system, while beak length, wing length and tail length differed most in appearance. And it was speculated that different food compositions lead to different changes in certain positions of the body, thus might shape an explorable trail, which needs to be investigated thoroughly.

\section{INTRODUCTION}

Lonchura striata and Copsychus saularis, who are common resident birds, belong to Passeriformes. They inhabit low mountains, hills and foot plains. Lonchura striata and Copsychus saularis are adaptable birds whose feathers are very bright, so they get high ornamental value. Both species are currently listed in the Red List of Endangered Species ver 3.1-Low Risk (LC) of the World Conservation Union (IUCN) in 2013. Although they are omnivorous bird, there are great differences in their staple ingredients (Honda et al., 1999; Lim et al., 2015; Siddique, 2018).

In recent years, the researches on the Lonchura striata mainly focus on the relationship between the neurobehavioral establishment and the development of vocal behavior (Mingxue, 2002), the selection of nests and the use of nesting materials are analyzed accordingly ( $\mathrm{Li}$ et al., 1991). For Copsychus saularis, the function of song, including courtship, protest and playfulness are researched (Jiang, 2003). These researches showed us that the changes of behavior of birds are due to the difference of environment and habitats. In order to figure out the effects of staple ingredients on the digestive tracts of two kinds of birds, we explored the morphology of their digestive tracts. 
The digestive system plays an important role in the digestive absorption, the secretory of enzymes, material transport and immune functions in organisms (Grajal, 1995). The morphological structure of digestive tract has close relationship with animals' diet and nutrient composition (Miles et al., 1984; Block et al., 1991; Zeffer et al., 2003). The changes of intestinal structural directly influence digestive functions (Zeffer et al., 2003). The study of morphological structure is the most important method in taxonomy, which provides detailed information for other studies in various areas of biology.

Lonchura striata and Copsychus saularis are passerine omnivorous birds, but their staple foods are different. Lonchura striata mainly feeds on herbivorous seeds, and Copsychus saularis is fond of eating insects. Will the difference of food between the two species lead the difference of appearance and structure of the digestive system? In this study, Lonchura striata and Copsychus saularis were selected and their appearance parameters (full length, mouth peak length, claw length, wing length, tarsal toe length, toe length and tail length) and digestive system parameters (beak, duodenum, jejunum, ileum, digestive tract length and total digestive tract weight) were measured in order to explore the structural differences in the digestive system in different genders and different species. Besides, we studied whether there were some differences in appearance and digestive systems between the two species of birds of different genders or same eating habits but different food compositions.

\section{MATERIALS AND METHODS}

\section{Experimental Animals}

In this experiment, 10 adult Lonchura striata (5-5 ) were collected near Paifang Street, Jialing District, Nanchong, Sichuan and 10 Copsychus saularis (5-5 ) were collected near Xishan Scenic Area in Nanchong City of Sichuan province.

\section{Experimental methods}

After a day of fasting, these birds were anesthetized with intramuscular injections of $25 \mathrm{mg} / \mathrm{kg}$ Nembutal (Lanospharma Laboratories Co.,Ltd, 57-33-0) and 80 mg/kg Ketaset (Zoetis Canada Inc., 2626-11-1), appearance parameters were measured and recorded, which included full length, mouth peak length, claw length, wing length, tarsal toe length, toe length and tail length. Then the birds were euthanized and dissected immediately and the digestive tracts were separated from the bodies of those birds, excess fat and connective tissue were carefully removed. Besides, the digestive system parameters were measured and recorded, including the length of bill, duodenum, jejunum, ileum, and total length and weight of digestive tract. Moreover, the digestive tract index was also calculated (Length index = Organ length/body length, Weight index = Organ weight/body weight). Specific measurement criteria were shown in Figure 1 and Figure 2 and particular experiments were displayed in Figure 3.

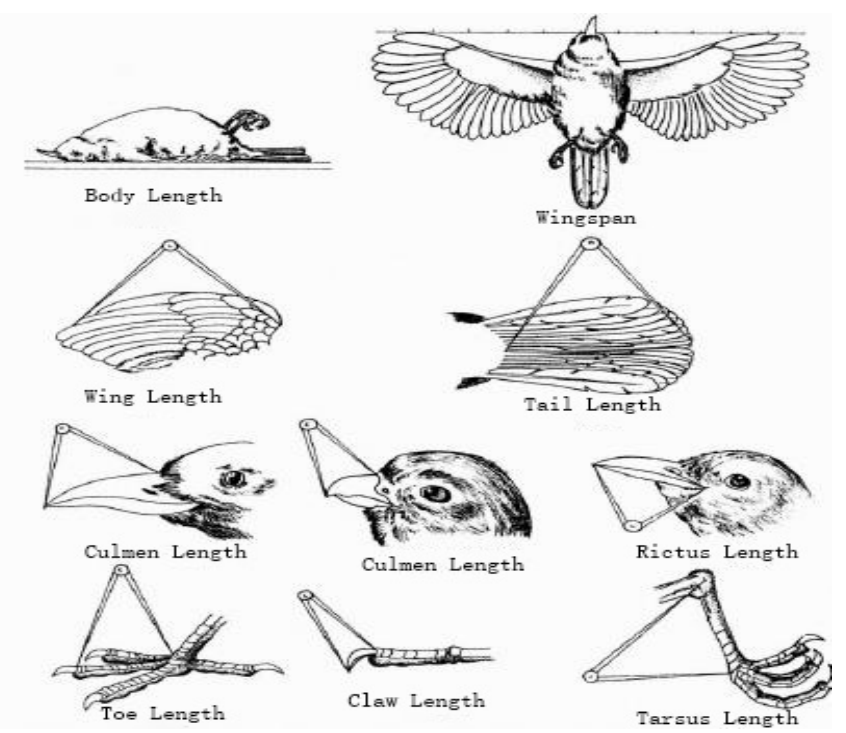

Figure 1 - Measurement method of appearance parameters.

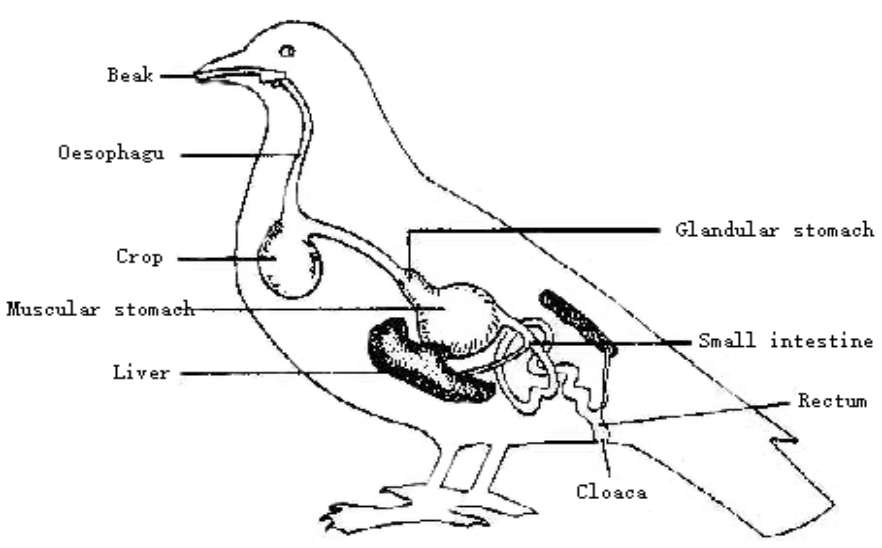

Figure 2 - Measurement method of digestive system parameters.

\section{Statistical analysis}

Mean and variance were used to compare the discrepancy of appearances parameters and the digestive system parameters between the two species. The comparison demonstrated the evolution of Lonchura striata and Copsychus saularis. To analyse the feeding habits characteristic of those birds, the digestive tract index was calculated. 
All calculations were conducted in IBM SPSS Statistics 20.0 with single sample t-test or paired sample t-test. All results were expressed as mean \pm standard deviation, and values of $p<0.05$ and $p<0.01$ were considered significant and highly significant respectively.

\section{RESULTS}

\section{Appearance parameter}

\section{Appearance parameters of Lonchura striata}

The upper body of the Lonchura striata is dark sandy brown with white feathers, and its waist is covered with white feathers, which is the unique characteristic of this kind of species. Other feathers color of males and females are similar (Figure1, 2). The average body weights of males and females are $11.68 \pm 0.13 \mathrm{~g}$ and $10.80 \pm 0.43 \mathrm{~g}$ respectively and the average body lengths are $110.45 \pm 2.08 \mathrm{~mm}$ and $105.93 \pm 3.40 \mathrm{~mm}$ respectively. There are no significant differences in body weight, body length, mouth peak length, claw length, wing length, tarsal toe length, toe length and tail length between the two genders $(p>0.05)$. The results are shown in Table 1.

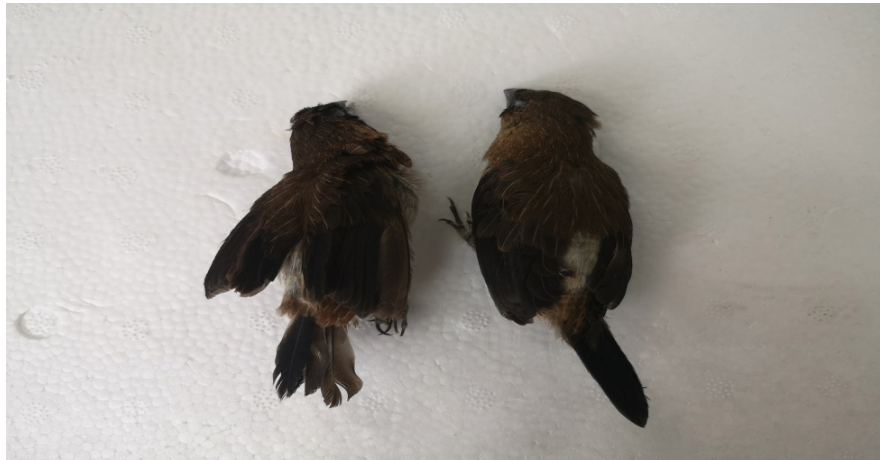

Figure 1 - Appearance of Lonchura striata ( $\mathbf{l}$ left, $\mathbf{\square}$ right).

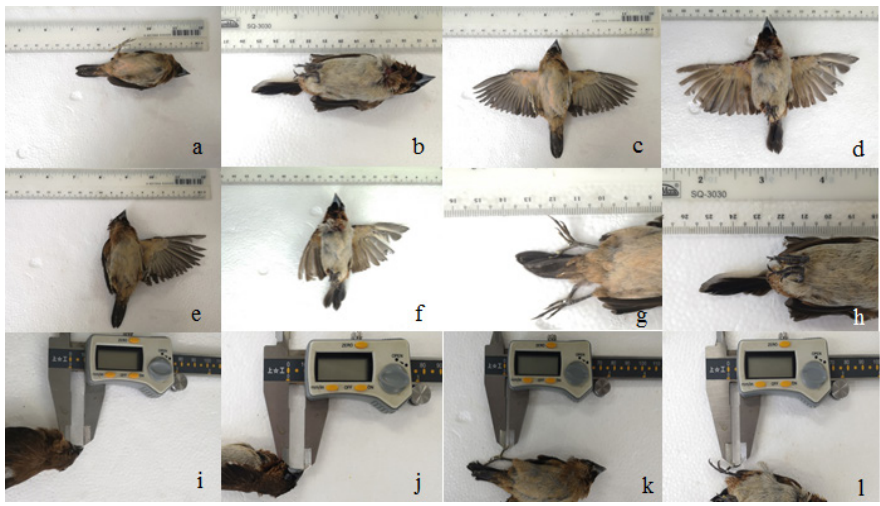

Figure 2 - Appearance measurement of Copsychus saularis.

$a, c, e, g, i$ and $k$ were female's body length, wingspan, wing length, tail length, culmen length and claw length, respectively. And $b, d, f, h, j$ and I were male's.

Table 1 - Appearance parameters of Lonchura striata.

\begin{tabular}{lcccccccc}
\hline Gender & Weight $(\mathrm{g})$ & Length $(\mathrm{mm})$ & Culmen $(\mathrm{mm})$ & Claw $(\mathrm{mm})$ & Wing $(\mathrm{mm})$ & Tarsus $(\mathrm{mm})$ & Toe $(\mathrm{mm})$ & Tail $(\mathrm{mm})$ \\
\hline $\boldsymbol{\square}$ & $11.68 \pm 0.13$ & $110.45 \pm 2.08$ & $11.71 \pm 0.26$ & $4.50 \pm 0.31$ & $49.90 \pm 0.99$ & $14.18 \pm 0.44$ & $11.94 \pm 0.99$ & $45.45 \pm 1.28$ \\
$\mathbf{q}$ & $10.80 \pm 0.43$ & $105.93 \pm 3.40$ & $9.59 \pm 1.23$ & $3.98 \pm 0.23$ & $49.59 \pm 0.90$ & $13.51 \pm 0.85$ & $12.66 \pm 0.77$ & $43.56 \pm 1.31$ \\
$p$ value & 0.665 & 0.871 & 0.962 & 0.354 & 0.541 & 0.550 & 0.775 & 0.098 \\
\hline
\end{tabular}

\section{Appearance parameters of Copsychus saularis}

The Copsychus saularis has black feathers from top to tail, black-brown feather in the middle, black edge in the fourth pair of tail feathers on the outside, and white tail feathers in the rest of the body. The other tail feathers are white, with the same color from chin to upper chest and face, and pure white feathers from lower chest to lower tail (Figure 3, 4). The average body weights of males and females are $31.99 \pm 1.90 \mathrm{~g}$ and $31.45 \pm 1.03 \mathrm{~g}$. Besides, the average body lengths of male and female are $191.39 \pm 2.13 \mathrm{~mm}$

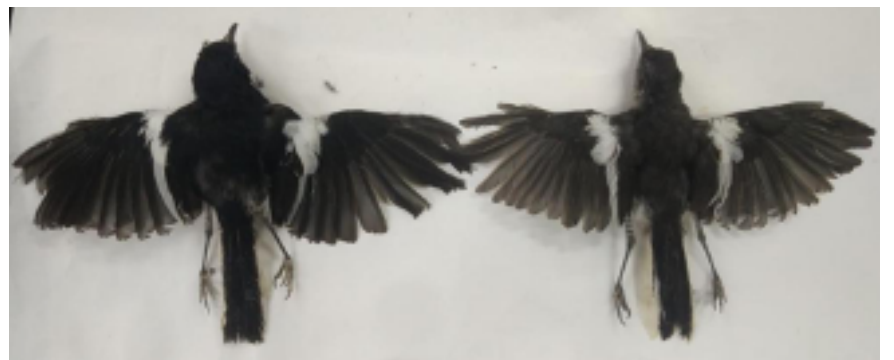

Figure 3 - Appearance of Copsychus saularis (

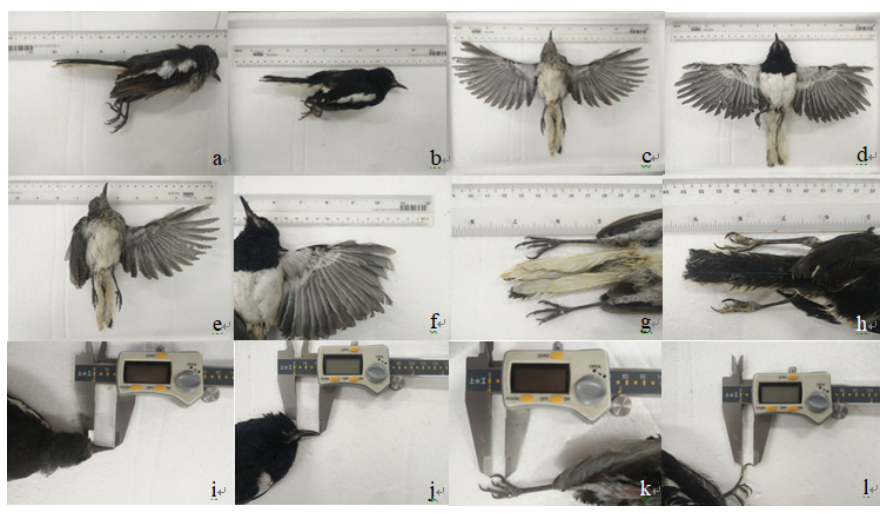

Figure 4 -Appearance measurement of Copsychus saularis.

$a, c, e, g, i$ and $k$ were female's body length, wingspan, wing length, tail length, culmen length and claw length, respectively. And $b, d, f, h, j$ and I were male's.

and $183.69 \pm 8.54 \mathrm{~mm}$ respectively. There are no significant differences in body weight, body length, mouth peak length, claw length, wing length, tarsal toe length, toe length, tail length and beak length between male and female birds ( $p>0.05)$. The results are shown in Table 2. 
Table 2 - Appearance parameters of Copsychus saularis.

\begin{tabular}{lcccccccc}
\hline Gender & Weight $(\mathrm{g})$ & Length $(\mathrm{mm})$ & Culmen $(\mathrm{mm})$ & Claw $(\mathrm{mm})$ & Wing $(\mathrm{mm})$ & Tarsus $(\mathrm{mm})$ & Toe $(\mathrm{mm})$ & Tail $(\mathrm{mm})$ \\
\hline $\boldsymbol{\square}$ & $31.99 \pm 1.90$ & $191.39 \pm 2.13$ & $18.4 \pm 0.47$ & $22.23 \pm 1.83$ & $93.82 \pm 4.96$ & $31.29 \pm 0.63$ & $7.47 \pm 0.51$ & $24.99 \pm 1.00$ \\
$\mathbf{D}$ & $31.45 \pm 1.03$ & $183.69 \pm 8.54$ & $16.6 \pm 0.55$ & $23.20 \pm 1.00$ & $90.04 \pm 4.26$ & $30.72 \pm 2.63$ & $6.84 \pm 0.39$ & $23.37 \pm 1.43$ \\
$p$ value & 0.466 & 0.206 & 0.815 & 0.207 & 0.738 & 0.085 & 0.572 & 0.505 \\
\hline
\end{tabular}

Comparison of appearance parameters of Lonchura striata and Copsychus saularis

By analyzing the overall appearance parameters of the two bird species, the weight, length, culmen, claw, wing, toe and tail between them we compared.
The result shows that the body size of the Copsychus saularis is generally larger than the Lonchura striata, and there are significant differences or highly significant differences $(p<0.05$ or $p<0.01)$ in the length of the beak, wing and tail between them (Table 3).

Table 3 - Comparisons of appearance Parameters between Lonchura striata and Copsychus saularis.

\begin{tabular}{|c|c|c|c|c|c|c|c|c|}
\hline Species & Weight (g) & Length $(\mathrm{mm})$ & Culmen (mm) & Claw (mm) & Wing (mm) & Tarsus (mm) & Toe (mm) & Tail (mm) \\
\hline Lonchura striata & $10.84 \pm 0.61$ & $109.38 \pm 2.81$ & $11.52 \pm 0.23$ & $4.52 \pm 0.36$ & $49.40 \pm 1.11$ & $13.74 \pm 0.63$ & $10.69 \pm 0.42$ & $44.75 \pm 1.23$ \\
\hline Copsychus saularis & $31.79 \pm 0.15$ & $186.87 \pm 5.20$ & $17.09 \pm 0.58$ & $22.9 \pm 0.67$ & $89.87 \pm 4.16$ & $29.81 \pm 0.67$ & $6.96 \pm 0.37$ & $23.49 \pm 0.99$ \\
\hline$p$ value & 0.130 & 0.132 & 0.006 & 0.355 & 0.003 & 0.775 & 0.745 & 0.025 \\
\hline
\end{tabular}

\section{Digestive system parameters}

\section{Digestive System Parameters of Lonchura striata}

Figure 5 Table 4 shows the average length of the digestive tract of male Lonchura striata as $16.35 \pm 0.52 \mathrm{~cm}$, digestive tract weight as $1.06 \pm 0.09 \mathrm{~g}$, beak length is $1.15 \pm 0.03 \mathrm{~cm}$, duodenum is $3.10 \pm 0.43 \mathrm{~cm}$, jejunum is $3.24 \pm 0.50 \mathrm{~cm}$, ileum and posterior is $7.00 \pm 0.69 \mathrm{~cm}$. The average value of female digestive tract length is $14.65 \pm 0.48 \mathrm{~cm}$, digestive tract weight is $0.98 \pm 0.04 \mathrm{~cm}$, beak length is $1.13 \pm 0.36 \mathrm{~cm}$, duodenum is $3.08 \pm 0.18 \mathrm{~cm}$, jejunum is $2.98 \pm 0.14 \mathrm{~cm}$, ileum and posterior is $6.56 \pm 0.33 \mathrm{~cm}$. There is no significant difference in the digestive system parameters between male and female birds ( $p>0.05$ ).

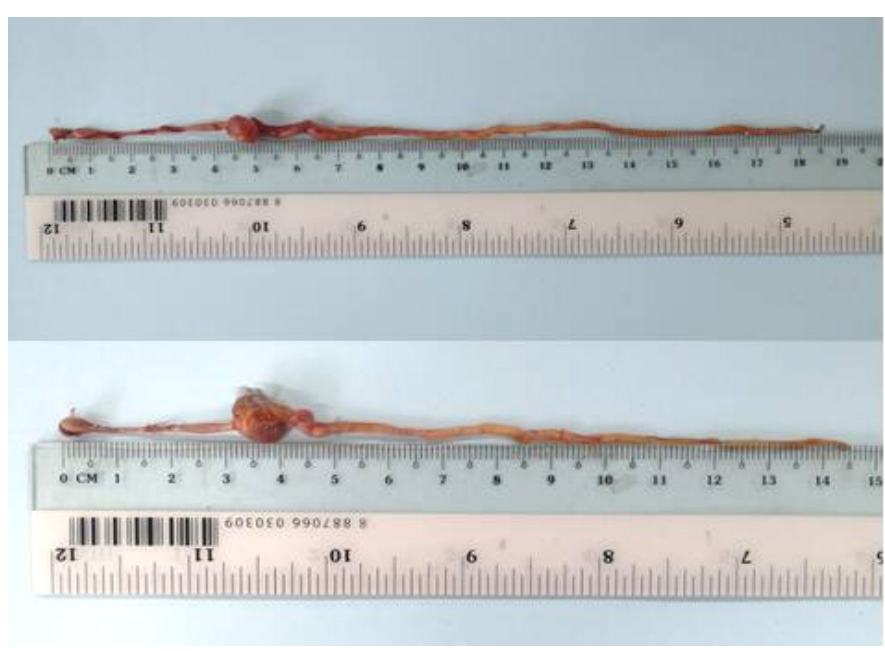

Figure 5 - Digestive System Parameters of Lonchura striata ( $\mathbf{\square}$ left, $\mathbf{\square}$ right).

Table 4 - Digestive system measurement of Lonchura striata.

\begin{tabular}{lcccccc}
\hline Gender & Bill $(\mathrm{cm})$ & Duodenum $(\mathrm{cm})$ & Jejunum $(\mathrm{cm})$ & lleum $(\mathrm{cm})$ & Length $(\mathrm{cm})$ & Weight $(\mathrm{g})$ \\
\hline $\boldsymbol{\square}$ & $1.15 \pm 0.30$ & $3.10 \pm 0.43$ & $3.24 \pm 0.50$ & $7.00 \pm 0.69$ & $16.35 \pm 0.52$ & $1.06 \pm 0.09$ \\
$\mathbf{q}$ & $1.13 \pm 0.36$ & $3.08 \pm 0.18$ & $2.98 \pm 0.14$ & $6.56 \pm 0.33$ & $14.65 \pm 0.48$ & $0.98 \pm 0.04$ \\
$p$ value & 0.807 & 0.609 & 0.051 & 0.647 & 0.684 & 0.776 \\
\hline
\end{tabular}

\section{Digestive system parameters of Copsychus saularis}

Figure 6 Table 5 shows the average length of digestive tract of male Copsychus saularis as $17.14 \pm 0.87 \mathrm{~cm}$, digestive tract weight is $2.05 \pm 0.05 \mathrm{~g}$, beak length is $2.59 \pm 0.44 \mathrm{~cm}$, duodenum is $3.95 \pm 0.08 \mathrm{~cm}$, jejunum is $3.95 \pm 0.08 \mathrm{~cm}$, ileum and posterior is $8.04 \pm 0.22 \mathrm{~cm}$ and that of female digestive tract length is $18.44 \pm 0.03 \mathrm{~cm}$, digestive tract weight is $2.49 \pm 0.11$, beak length was $2.26 \pm 0.70 \mathrm{~cm}$, duodenum is $4.10 \pm 0.06 \mathrm{~cm}$, jejunum is $3.62 \pm 0.11 \mathrm{~cm}$, ileum and posterior is $8.52 \pm 0.48 \mathrm{~cm}$. No significant difference is observed in the digestive system parameters between male and the female birds ( $p>0.05)$, as showed in Table 5.

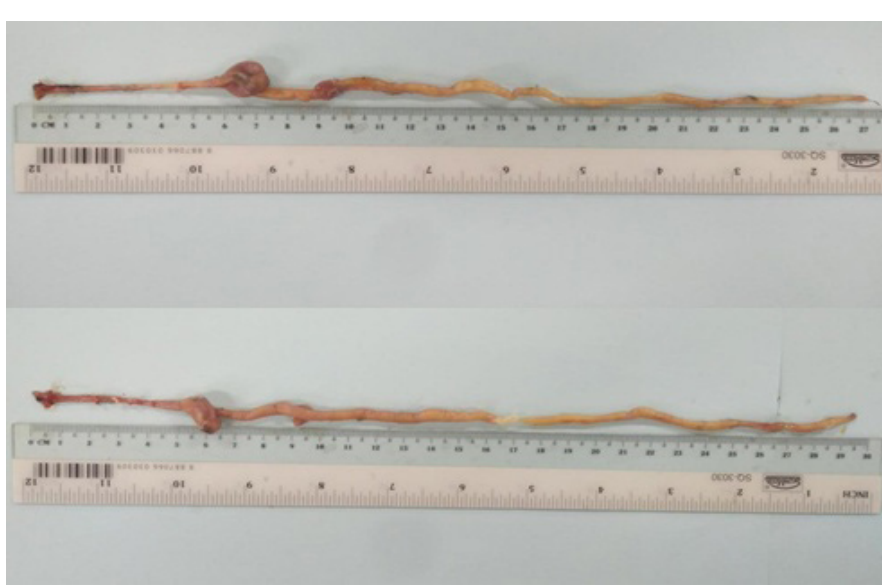

Figure 6 - Digestive System Parameters of Copsychus saularis ( right). 
Table 5 - Digestive system measurement of Copsychus saularis.

\begin{tabular}{lcccccc}
\hline Gender & Bill $(\mathrm{cm})$ & Duodenum $(\mathrm{cm})$ & Jejunum $(\mathrm{cm})$ & lleum $(\mathrm{cm})$ & Length $(\mathrm{cm})$ & Weight $(\mathrm{g})$ \\
\hline $\boldsymbol{\square}$ & $2.59 \pm 0.44$ & $3.95 \pm 0.08$ & $3.80 \pm 0.06$ & $8.04 \pm 0.22$ & $17.14 \pm 0.87$ & $2.05 \pm 0.05$ \\
$\mathbf{\square}$ & $2.26 \pm 0.70$ & $4.10 \pm 0.06$ & $3.62 \pm 0.11$ & $8.52 \pm 0.48$ & $18.44 \pm 0.03$ & $2.49 \pm 0.11$ \\
\hline value & 0.434 & 0.492 & 0.351 & 0.332 & 0.106 & 0.183 \\
\hline
\end{tabular}

\section{Comparison of digestive system parameters of} Lonchura striata and Copsychus saularis

There are significant differences in duodenal parameters between the Lonchura striata and the Copsychus saularis $(p<0.05)$, but there are no significant differences in other parameters (bill, jejunum, ileum, length and weight) ( $p>0.05$ ) (Table 6).

\section{Digestive system index}

Digestive system index correlation formula: length index = organ length/body length, weight index = organ weight/body weight.

\section{Digestive system index of Lonchura striata}

As showed in Table 7, the average length index of ileum and its posterior segment in males is larger than that in females. The average length and weight of duodenum, jejunum, intestine, digestive tract index in females are larger than those in males. However, there are no significant differences between the males and the females ( $p>0.05$ ). The length index of each tissue is ranged from large to small, including ileum and its posterior segment, duodenum and jejunum.

Table 6 - Comparison of digestive tract system parameters between Lonchura striata and Copsychus saularis.

\begin{tabular}{lcccccc}
\hline Species & Bill $(\mathrm{cm})$ & Duodenum $(\mathrm{cm})$ & Jejunum $(\mathrm{cm})$ & Ileum $(\mathrm{cm})$ & Length $(\mathrm{cm})$ & Weight $(\mathrm{g})$ \\
Lonchura striata & $1.15 \pm 0.40$ & $3.05 \pm 0.22$ & $2.58 \pm 0.18$ & $7.25 \pm 0.79$ & $15.1 \pm 0.38$ & $0.93 \pm 0.07$ \\
Copsychus saularis & $2.44 \pm 1.13$ & $4.05 \pm 0.06$ & $3.76 \pm 0.06$ & $8.45 \pm 0.35$ & $17.78 \pm 0.73$ & $2.23 \pm 0.13$ \\
$p$ value & 0.106 & 0.04 & 0.075 & 0.23 & 0.277 & 0.292 \\
\hline
\end{tabular}

Table 7 - The index of digestive system out of Lonchura striata.

\begin{tabular}{lccccc}
\hline Gender & Duodenum index & Jejunum index & lleum index & Digestive tract index & Weight index \\
\hline $\boldsymbol{\square}$ & $0.27 \pm 0.02$ & $0.30 \pm 0.08$ & $0.66 \pm 0.09$ & $1.32 \pm 0.03$ & $0.07 \pm 0.01$ \\
$\mathbf{p}$ & $0.28 \pm 0.01$ & $0.28 \pm 0.03$ & $0.63 \pm 0.08$ & $1.49 \pm 0.11$ & $0.10 \pm 0.01$ \\
\hline
\end{tabular}

\section{Digestive system index of Copsychus saularis}

As shown in Table 8, the average length index of the oesophagus, duodenum, ileum and the following parts of the Copsychus saularis is larger in females than in males, and the jejunum is longer in males than in females. The length of each tissue is ranged from large to small, including ileum and posterior segment, duodenum and jejunum.

Table $\mathbf{8}$ - The index of digestive system out of Copsychus saularis.

\begin{tabular}{lccccc}
\hline Gender & Duodenum index & Jejunum index & lleum index & Digestive tract index & Weight index \\
\hline $\boldsymbol{\square}$ & $0.20 \pm 0.00$ & $0.20 \pm 0.00$ & $0.41 \pm 0.01$ & $0.88 \pm 0.05$ & $0.06 \pm 0.00$ \\
$\mathbf{p}$ value & $0.22 \pm 0.00$ & $0.20 \pm 0.01$ & $0.47 \pm 0.03$ & $1.03 \pm 0.01$ & $0.07 \pm 0.00$ \\
\hline
\end{tabular}

\section{Comparison of digestive system index between Lonchura striata and Copsychus saularis}

Comparing the indexes of digestive systems of Lonchura striata and Copsychus saulari, it could be observed that the duodenal index of the Lonchura striata is significantly different $(p<0.01)$, while the other tissue indexes show no significant differences (p>0.05).

Table 9 - Comparison of digestive system index between Lonchura striata and Copsychus saularis.

\begin{tabular}{|c|c|c|c|c|c|}
\hline Gender & Duodenum index & Jejunum index & Ileum index & Digestive tract index & Weight index \\
\hline Lonchura striata & $0.28 \pm 0.02$ & $0.24 \pm 0.02$ & $0.66 \pm 0.06$ & $1.38 \pm 0.04$ & $0.09 \pm 0.01$ \\
\hline Copsychus saularis & $0.22 \pm 0.01$ & $0.20 \pm 0.01$ & $0.44 \pm 0.03$ & $0.96 \pm 0.06$ & $0.07 \pm 0.00$ \\
\hline$p$ value & 0.000 & 0.243 & 0.247 & 0.454 & 0.400 \\
\hline
\end{tabular}




\section{DISCUSSION}

The morphological characteristics of birds are closely related to their living habits, and the unique lifestyle of each species ensures its reproduction on the earth (Grajal, 1995). According to their different lifestyle, appearance and digestive system, they can be divided into different ecological groups, which indirectly reflect the differences in feeding habits of birds and the characteristics of food energy absorption (Sun, 2009). The morphological characteristics of the digestive tract of the birds are closely related to the type, nature and energy of the food they eat (Caviedesvidal et al., 2000). Karasov (2011) pointed out that the difference of feeding habits was the main reason for the difference of digestive tract morphology among species in migrant birds. In this study, we measured the appearance and digestive system parameters of two passerine birds, Lonchura striata and Copsychus saularis. We explored their living habits and foodchoosing properties, and then figured out whether there were differences in appearance and digestive system between birds with the same species but different genders and between Lonchura striata and Copsychus saularis. In the study of the appearance of the two birds, the analysis data showed that the male of the two birds was usually larger and stronger than the female. Males were longer than females in total length, weight, mouth peak length, claw length, wing length, tarsus length and tail length. This may be related to the reproductive strategy, a strong body represented good physical function to attract females to mate and to ensure the reproduction of species.

Through analysis of the appearance parameters of Lonchura striata and Copsychus saularis, we found that the peak length of beak, wing length and tail length of Lonchura striata are smaller than Copsychus saularis $(p<0.05)$. The beak is an important organ for birds to feed, its morphological structure and function vary significantly according to the different feeding habits of birds (Mallarino et al., 2012). The wings and tails of birds play an important role in flight and foraging (Clarke et al., 2010). From the analysis of their food habits, the Lonchura striata and the Copsychus saularis are omnivorous birds, and their feeding selectivity is relatively small, so they tend to maintain their growth and reproduction by increasing the foraging probability, the number of food and broadening the feeding niche (Barnea et al., 1991). There are some differences in the choice of food ingredients between the two species. Studies have shown that the Lonchura striata mainly live on grains, grass seeds, fruits, leaves, buds and other plant foods, occasionally eat animal foods such as Lepidoptera insects, while Copsychus saularis prefer to eat insects, and rarely eat plant seeds (Honda et al., 1999; Lim et al., 2015). Lonchura striata collect plant food by pecking. However, the Copsychus saularis usually eats by whole swallowing, pecking and picking up (Lim et al., 2015). The insects they eat are more flexible and difficult to catch, therefore, to improve the probability of predation, they need larger wings, longer sharp beaks and claws. However, the tail length of the Copsychus saularis is shorter than that of the Lonchura striata. We think that the Copsychus saularis need a more active body to prey, shorter tail feathers can aviod the wagging of tail, so as to improve its predation efficiency. For other birds, such as Liocichla omeiensis (Xu et al., 2006), as a phytophagous bird, the average beak length is about $1.4 \mathrm{~cm}$ and wing length of about $7 \mathrm{~cm}$, Falco Tinnunculus is a carnivorous bird with a beak of 6-9 cm and hooked appearance, which is conducive to tearing animals carcasses, and its wing length is about $81.3 \mathrm{~cm}$ (Niu et al., 2004). The composition of foraging determines the evolution of their external form, which is similar to the results of this study.

Changes in digestive tract morphology depend on animal food intake and energy consumption in different ecological environments (Niu et al., 2004; Terry et al., 1995; Du et al., 2001; Bogue, 1993; Chikilian et al., 2015). McWillimas and Karasov (2001) pointed out that there were significant differences in digestive tract length and weight between migratory birds, which can further reflect the food habits of animals. The total digestive tract length of phytophagous birds is longer than that of omnivorous birds, while that of insectfeeding birds is the shortest (Mcwilliams et al., 2001). In our study, the results showed that there was no significant difference between males and females in both Lonchura striata and Copsychus saularis ( $p>0.05$ ). Additionally, the length of each intestinal segment and the weight of the whole digestive tract of the two birds were analyzed. There were significant differences in the duodenum $(p<0.05)$, while there were no significant differences in the other intestinal segments. Duodenal is the main organ for food digestion and absorption, with the help of the bile and pancreatic juice which are injected into the duodenum to participate in food digestion. The changes of duodenum reflect the digestive absorption index of nutrients and energy demand of birds. The aforementioned Lonchura striata and Copsychus saularis are omnivorous birds, but 
the staple food compositions of them are different. Copsychus saularis mainly consumes small insects, which are difficult to digest due to chitin and a large amount of protein in the shells. These insects are preliminarily digested in the stomach, then enter the small intestine and digest thoroughly. The duodenum length of Copsychus saularis is significantly longer than that of Lonchura striata, which ensures the thoroughness of protein digestion. As a result, we can conclude that the composition of food also affects the evolution of the digestive tract.

We also calculated the digestive system index of Lonchura striata and Copsychus saularis in this study. The related researches explain that the digestive tract index can reflect the feeding characteristics laterally (Wu et al., 2013). However, there is no specific report on the digestive tract index of birds. Based on the digestive tract index obtained in this study, we think that the average digestive tract length and digestive tract weight of omnivorous birds are about 1.17 and 0.08 respectively. There is no significant difference in digestive tract indexes between males and females ( $p>0.05)$, but there is a highly significant difference in duodenal index $(p<0.01)$ between the two species, which indicates the difference in the digestive system. Those results emphasize the important role of the duodenum in the digestive process, indicating that the choice of food ingredients would influence the digestive tract morphology. Hence, the future direction is to explore the difference of the morphological structure and cell composition of the digestive tract, so that we can express this research phenomena clearly.

\section{CONCLUSION}

There are significant differences between the two birds in their appearance, such as the mouth peak length, wing length, tail length and digestive structure, indicating different appearances evolved due to different staple feeding habits to improve their predation rate and adapt to different environments. Besides, the duodenum of the two kinds of birds have significant discrepancy, which relies on the composition foods.

\section{ACKNOWLEDGEMENTS}

The authors would like to thank the co-workers of China West Normal University for their assistance in performing the experiment and the analysis. The study was supported by the Scientific Research Fund of
SiChuan Provincial Education Department (project no. 17ZB0425) and the Fundamental Research Funds of China West Normal University (project no. 17YC349, 16E012).

\section{REFERENCES}

Barnea A, Yomtov Y, Friedman J. Does ingestion by birds affect seed germination? Functional Ecology 1991;5(3):394-402

Block WM, Brennan LA, Gutiérrez RJ. Ecomorphological relationships of a guild of ground-foraging birds in northern California, USA. Oecologia 991;87(3):449-458.

Bogue DBA. Responses of the gut to moderate energy demands in a small Herbivore (Microtus pennsylvanicus). Journal of Mammalogy $1993 ; 74(1): 59-68$

Caviedes-Vidal E, Afik D, Rio CMD, Karasov WH. Dietary modulation of intestinal enzymes of the house sparrow (Passer domesticus): testing an adaptive hypothesis. Comparative Biochemistry and Physiology - Part A: Molecular \& Integrative Physiology 2000;125(1):11-24.

Chikilian M, De Speroni NB. Comparative study of the digestive system of three species of tinamou. I. crypturellus tataupa, nothoprocta cinerascens, and nothura maculosa (aves: tinamidae). Journal of Morphology 2015;228(1):77-88.

Clarke JA, Zhou ZH, Zhang FC. Insight into the evolution of avian flight from a new clade of early cretaceous ornithurines from China and the morphology of Yixianornis grabaui. Journal of Anatomy 2010;208(3):287-308.

Du WG, Bao YX, Liu JK. A comparison on length and weight of digestive tract among seven species of rodents (muridae). Acta Theriologica Sinica 2001;21(4):264-270.

Grajal A. Structure and function of the digestive tract of the Hoatzin (Opisthocomus hoazin): a folivorous bird with foregut fermentation. The Auk 1995;112(1):20-28.

Honda E, Okanoya K. Acoustical and syntactical comparisons between songs of the white-backed Munia (Lonchura striata) and its domesticated strain, the bengalese finch (Lonchura striata var. domestica). Zoological Science 1999;16(2):319-326

Jiang SR. Vocal behavior of magpie robin (Copsychus saularis) in Hangzhou, China. Sichuan Journal Zoology 2003;22(3):144-146.

Karasov WH. Digestive physiology: a view from molecules to ecosystem. American Journal of Physiology-Regulatory, Integrative and Comparative Physiology 2011;301(2):276-284.

Li PJ, Martin TE. Nest-site selection and nesting success of cavity-nesting birds in high elevation forest drainages. The Auk 1991;108(2):405-418.

Lim HC, Zou F, Sheldon FH. Genetic differentiation in two widespread, open-forest bird species of Southeast Asia (Copsychus saularis and Megalaima haemacephala): insights from ecological niche modeling. Current Zoology 2015;61(5):922-934.

Mallarino R, Campas O, Fritz J, Burns KJ, Weeks OG, Brenner MP, et al. Closely related bird species demonstrate flexibility between beak morphology and underlying developmental programs. Proceedings of the National Academy of Sciences USA 2012;109(40):16222-16227.

Mcwilliams SR, Karasov WH. Phenotypic flexibility in digestive system structure and function in migratory birds and its ecological significance. Comparative Biochemistry and Physiology - Part A Molecular \& Integrative Physiology 2001;128:577-591. 
Miles DB, Ricklefs RE. The correlation between ecology and morphology in deciduous forest passerine birds. Ecology 1984;65(5):1629-1640.

Mingxue Z. Neural development of vocal behavior in striated mannikin (Lonchura striata swinhoei). Acta Zoologica Sinica 2002;48(1):50-57.

Niu HX, Bu YZ, Lu QW, Gao Q. Morphological observation of digestive system of Falco Tinnunculus. Journal of Henan Normal University 2004;32(1):81-83.

Siddique YH. Breeding behavior of Copsychus saularis in indian-subcontinent: a personal experience. International Journal of Zoologial Research 2008;4(2):135-137.

Sun YM. Morphological comparison of the digestive systems from 10 species of birds in 4 kinds of ecological groups. Sichuan Journal of Zoology 2009;28(3):379-381.
Terry L, Edward B. Seasonal changes in gut capacity in the whitefooted mouse (Peromyscus leucopus) and meadow vole (Microtus pennsylvanicus). Canadian Journal of Zoology 1995;73(2):243-252.

Wu B, Fan HP, Zhong QF, Weng ZT, Liang P, Chen DH, et al. Studies on the digestive tube index and the activity distribution of two digestive protease activity in NEW GIFT Tilapia(Oreochromis niloticus). Fujian Journal of Agricultural Science 2013;28(8):727-730.

Xu H, Guo YS. Morphology of digestive system of Liocichla omeiensis. Sichuan Journal of Zoology 2006;25(4):841-4.

Zeffer A, Johansson LC, Marmebro A. Functional correlation between habitat use and leg morphology in birds (Aves). Biological Journal of the Linnean Society 2003;79(3):461-484. 